\title{
Leydig cell tumor of the testis with azoospermia and elevated delta4 androstenedione: case report
}

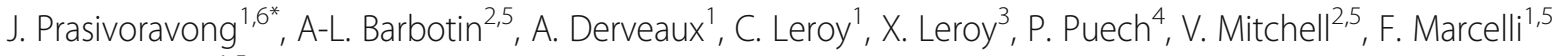
and J-M. Rigot ${ }^{1,5}$

\begin{abstract}
Background: Secreting interstitial cell (Leydig cell) tumors are rare. In adults, the clinical picture and steroid levels are variable.

Case presentation: This paper presents a case of left testicular tumor, showing azoospermia with normal serum level of total testosterone, collapsed FSH and LH, and high delta4 androstenedione. Histopathological investigation revealed a Leydig cell tumor. TESE allowed spermatozoa extraction and freezing. Testicular histology found hypospermatogenesis and germ-cell aplasia with interstitial fibrosis. Surgical resection of the tumor resulted in normalization of gonadotropins and fall in serum delta4 androstenedione to subnormal levels in the postoperative period confirming that the tumor was secreting delta4 androstenedione. It was hypothesized that high delta4 androstenedione resulted in intra tumoral $17 \beta-$ HSD overtaken by delta 4 androstenedione or that $17 \beta-H S D$ activity in the tumor was different from that of normal Leydig cells. Three months after surgery sperm analysis found a complete recovery of spermatogenesis. A spontaneous pregnancy occurred 3 months after surgery and a girl was born.
\end{abstract}

Conclusions: In this case, the diagnosis of testicular Leydig cell tumor secreting delta4 androstenedione was made in a context of azoospermia.

Keywords: Azoospermia, Infertility, Hormone secreting testicular tumor, Leydig cell tumor, delta4 androstenedione, TESE

\section{Résumé}

Introduction: Les tumeurs testiculaires interstitielles (ou tumeurs testiculaires à cellules de Leydig) à expression endocrine sont rares. Chez l'adulte le tableau clinique et le bilan hormonal sont variables.

(Continued on next page)

\footnotetext{
* Correspondence: julie.prasivoravong@chru-lille.fr

${ }^{1}$ Department of Andrology, Lille University Hospital, Lille, France

${ }^{6}$ Department of Andrology, CHRU Lille, Hôpital Calmette, Boulevard du

Professeur Leclercq, 59037 Lille Cedex, France

Full list of author information is available at the end of the article
} 
(Continued from previous page)

Présentation du cas: Cet article présente le cas d'une tumeur testiculaire gauche dans un contexte d'azoospermie. Le bilan hormonal montre des gonadotrophines effondrées, une testostéronémie normale et une delta4 androstenedione augmentée. L'examen anatomopathologique a mis en évidence une tumeur à cellule de Leydig. La TESE a permis l'extraction et la congélation de spermatozoïdes. L'histologie a retrouvé un aspect mixte d'hypospermatogenèse diminuée incomplète et d'aplasie. Dans les suites de l'orchidectomie partielle gauche les taux de gonadotrophines se sont normalisés ainsi que le taux de delta4 androstenedione. L'hypothèse physiopathologique est que l'augmentation de la delta4 androstenedione résulte de la sursaturation de la $17 \beta$-HSD intra-tumoral ou que l'activité de la 17 B-HSD intra-tumoral est différente de celle dans les cellules de Leydig normales. Trois mois après la chirurgie, le spermogramme a montré une normalisation des paramètres spermatiques et une grossesse spontanée est survenue permettant la naissance d'une petite fille.

Conclusion: Dans ce cas clinique, le diagnostic de tumeur testiculaire à cellule de Leydig sécrétant de la delta4 androstenedione a été fait dans un contexte d'azoospermie.

Mots clés: Azoospermie, Infertilité, Tumeur testiculaire à sécrétion endocrine, Tumeur à cellules de Leydig, delta4androstenedione, TESE

\section{Background}

Testicular neoplasms represent $1-1.5 \%$ of all tumors in men. Those derived from the interstitial cells of Leydig are rare, constituting $1 \%$ of testicular tumors. Hormone secreting interstitial cell tumors are more unusual than non-secreting interstitial tumors. In young males, the tumor is usually associated with precocious puberty [1], whereas in adults, the clinical picture and steroid levels are variable [2-20]. This paper reports a case of testicular Leydig cell (interstitial cell) tumor secreting delta4 androstenedione in a patient with azoospermia.

\section{Case presentation}

A 44 year old man was referred to our clinic for secondary infertility; he had no medical or surgical history or medical treatment. He was a butcher and married.

In 2009, he consulted another medical center for primary infertility. His medical history included no testicular trauma, no inguino scrotal surgery, no cryptorchidism, no professional exposure, no tobacco, no alcohol, or drug consumption. Semen analysis is summerized in Table 1.

Serum level of total testosterone was $5.03 \mathrm{mg} / \mathrm{L}$, FSH 1.0 IU/L. Spermoculture found ureaplasma urealyticum.

Scrotal ultrasonography (Table 2) revealed:

Table 1 Semen analyses

\begin{tabular}{llll}
\hline & 2009 & Under 2014 & Under 3 months \\
\hline Volume $(\mathrm{mL})$ & 4.2 & 4.3 & 3.5 \\
Spermatozoa (10\% /ejaculate) & 0.78 & 0 & 259 \\
Progressive motility (\%) & 19 & 0 & 60 \\
Typical spermatozoa (\%) & $\mathrm{NF}$ & 0 & 33 \\
\hline
\end{tabular}

NF not feasible
Right testis: Normal in size and echotexture, without a focal lesion; normal epididymides; no varicocele; normal vasculature at Doppler examination. Left testis: a left hypoechoic polylobulated intratesticular mass measuring $30 \times 16 \mathrm{~mm}$, including numerous septa, and showing high vasculature at Doppler examination.

At that time, ofloxacine $200 \mathrm{mg}$ twice per day during 15 days was prescribed. A spontaneaous pregnancy occurred in 2009 and a boy was born in 2010 (3800 g). Between 2009-2014 the patient had no follow-up for this mass.

In 2014 the patient consulted a doctor in our clinic as he wished to have another child. Semen analyses showed strict azoospermia with normal volume (Table 1).

Physical examination showed a normal andrological development, testes were present in the scrotum, a slightly indurated mass could be felt in the upper pole of the left testis. Right testis was hypotrophic, seminal conducts were felt. There was neither gynecomastia nor any sign of hypercortisolism.

Scrotal ultrasonography found (Table 2) a hypotrophic right testicle $(8.5 \mathrm{~mL})$, but a hypoechoic lobulated mass was visible in the left testicle with heterogeneous echotexture, measuring $32 \times 31 \times 23 \mathrm{~mm}$, with slight vasculature at Doppler examination.

Serum analyses are described in Table 3. Total testosterone was measured by RIA using the Coat-ACount Kit (Siemens Diagnostics, Inc., Los Angeles, CA, USA). The assay's limit of quantification was $0.14 \mathrm{nmol} / \mathrm{L}(0.04 \mathrm{ng} / \mathrm{mL})$ and the interassay $\mathrm{CV}$ was between 5.9 and $11.0 \%$ for a range of concentrations between 0.76 and $13 \mathrm{ng} / \mathrm{mL}$. The FSH, LH, and estradiol were measured using chemiluminescent, two-site immunoassays on a multiparameter analyzer 
Table 2 Scrotal ultrasonography

\begin{tabular}{|c|c|c|c|}
\hline & 2009 & 2014 before surgery & $\begin{array}{l}3 \text { months after } \\
\text { surgery }\end{array}$ \\
\hline $\begin{array}{l}\text { Right } \\
\text { testis }\end{array}$ & $\begin{array}{l}\text { Normal in size and echotexture, without focal lesion; normal } \\
\text { epididymides; no varicocele; normal vasculature at Doppler } \\
\text { examination }\end{array}$ & Normal echotexture Volume $8.5 \mathrm{~mL}$ & $\begin{array}{l}\text { Normal } \\
\text { echotexture } \\
\text { Volume } 15.7 \mathrm{~mL}\end{array}$ \\
\hline $\begin{array}{l}\text { Left } \\
\text { testis }\end{array}$ & $\begin{array}{l}\text { Presence of a } 30 \times 16 \mathrm{~mm} \text { polylobulated intratesticular mass, } \\
\text { with low echogenicity, numerous septa, and high vasculature } \\
\text { at Doppler examination }\end{array}$ & $\begin{array}{l}\text { Low echogenicity intratesticular lobulated mass, with } \\
\text { heterogeneous echotexture, low echogenicity, measuring } \\
32 \times 31 \times 23 \mathrm{~mm} \text {, with slight vasculature at Doppler } \\
\text { examination }\end{array}$ & $\begin{array}{l}\text { Rearranged } \\
\text { aspect } \\
\text { secondary to } \\
\text { surgery } \\
\text { Volume } 12 \mathrm{~mL}\end{array}$ \\
\hline
\end{tabular}

(Architect; Abbott Laboratories). Delta4 androstenedione was measured in duplicate by radioimmunoassay using a kit provided by Beckman Coulter Immunotech. The percentage of testosterone crossreactivity was $0.5 \%$ with androstenedione and $0.02 \%$ with estradiol.

A marked increase in androstenedione levels and suppressed gonadotropin levels were found which are likely to contribute to the failure of spermatogenesis. Normal Dehydroepiandrosterone Sulfate argues against adrenal hyperandrogenism.

Abdomen and Thorax Computed Tomography (CT) imaging were normal (no adrenal gland abnormality and no secondary lesions).

Table 3 Hormonal results in 2014

\begin{tabular}{lll}
\hline & Normal range & Patient \\
\hline LH IU/L & $0.60-12$ & $<0.1$ \\
Total testosterone $\mathrm{ng} / \mathrm{mL}$ & $2.30-6.7$ & 4.61 \\
Testosterone/SBP & $28-78$ & 46.19 \\
Free testosterone pmol/L & $188-444$ & 311.04 \\
FSH IU/L & $1.2 .-7.8$ & 0.2 \\
Inhibin B pg/mL & $92-316$ & 54 \\
Delta4 androstenedione $\mathrm{ng} / \mathrm{mL}$ & $0.4-1.5$ & 10.40 \\
17 OH progesterone $\mathrm{ng} / \mathrm{mL}$ & $0.5-2.5$ & 1.07 \\
Dehydroepiandrosterone Sulfate $\mu \mathrm{mol} / \mathrm{L}$ & $1.7-12.8$ & 6.0 \\
Estradiol pg/mL & $9-62$ & 26 \\
LDH IU/L & $135-225$ & 214 \\
Human CG IU/L & $<2.5$ & $<2$ \\
Alfa foeto protein $\mu \mathrm{gg} / \mathrm{L}$ & $<10$ & 1 \\
Cortisol (8 AM) $\mu \mathrm{gg} / \mathrm{I00} \mathrm{mL}$ & $9-22$ & 9.8 \\
ACTH pg/mL & $<46$ & 41
\end{tabular}

IU international unit

$n g / m L$ nanogram/milliliter

pmol/L picomole/liter

IU/L international unit/liter

$\mathrm{pg} / \mathrm{mL}$ picogram/milliliter

$\mu \mathrm{mol} / \mathrm{L}$ micromole/liter

$\mu \mathrm{g} / \mathrm{L}$ microgram/liter

$\mu \mathrm{g} / 100 \mathrm{~mL}:$ microgram/100 milliliter
The committee on tumoral diseases agreed on the decision to perform a testis-sparing surgery with extemporaneous histological examination. We decided to perform a testicular sperm extraction (TESE) at the same time. TESE allowed spermatozoa extraction with freezing.

Surgical resection of the tumor (Fig. 1) allowed a tumor of $35 \times 30 \times 17 \mathrm{~mm}$ to be removed.

Immunostaining was performed on an automated immunostainer (Benchmark, Ventana, France) with antibodies to Inhibin A (Ventana, prediluted, pretreatment: EDTA pH 7.8 for $60 \mathrm{~min}$ ) and to SALL4 (Sigma, Dilution: 1/1500, pretreatment: EDTA pH 7.8 for $60 \mathrm{~min}$ ). All tumor cells were diffusely and strongly stained with antibody to Inhibin A corresponding to Leydig cell tumor and were completely negative to antibodies to SALL4 showing that there was no germ cell contingent (Figs. 2, 3 and 4).

The testicular histology found hypospermatogenesis and germ-cell aplasia with interstitial fibrosis (Fig. 5).

Surgical resection of the tumor (Fig. 1) resulted in normalization of gonadotropins and fall in serum delta4 androstenedione to subnormal levels in the postoperative period confirming that the tumor was secreting delta4 androstenedione (Table 4).

We hypothesized that high delta4 androstenedione resulted in intra tumoral $17 \beta$-HSD overtaken by a delta 4 androstenedione excess or that 17 betaHSD activity in the tumor was different from that of normal Leydig cells (Fig. 6).

Scrotal ultrasonography 3 months after surgery described a normal right testis which had increased in size (volume $15 \mathrm{~mL}$ ) and a left testis with a rearranged aspect secondary to surgery (Table 2).

Three months after surgery semen analyses showed a complete recovery of spermatogenesis (Table 1). A spontaneous pregnancy occurred, 3 months after surgery and a girl was born in 2015 (3450 g).

\section{Discussion}

To the authors' knowledge only one case of androstenedione secreting testicular Leydig cell tumors associated 


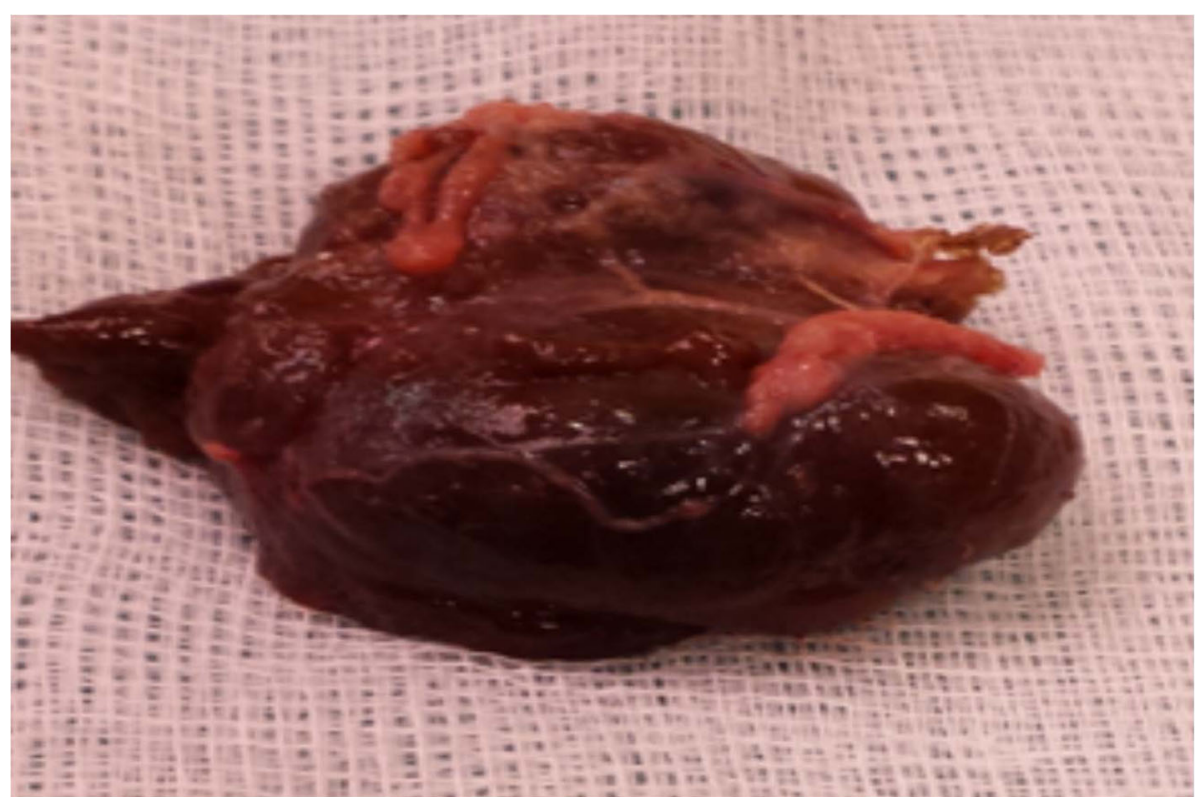

Fig. 1 Surgical resection of the tumor. Tumor of $35 \times 30 \times 17 \mathrm{~mm}$

with azoospermia has been reported previously [2]. In that case, serum levels of testosterone, dihydrotestosterone, $5 \alpha$-androstane-3 $3 \alpha, 17 \beta$ diol and oestradiol were normal and oestrone was moderately increased. In contrast androstenedione was extremely elevated. Testosterone levels in the spermatic vein were decreased indicating a partial deficiency of $17 \beta$ hydroxysteroid dehydrogenase in the tumoral tissue. Twenty-eight months after surgery, all sex steroids including androstenedione were normal.

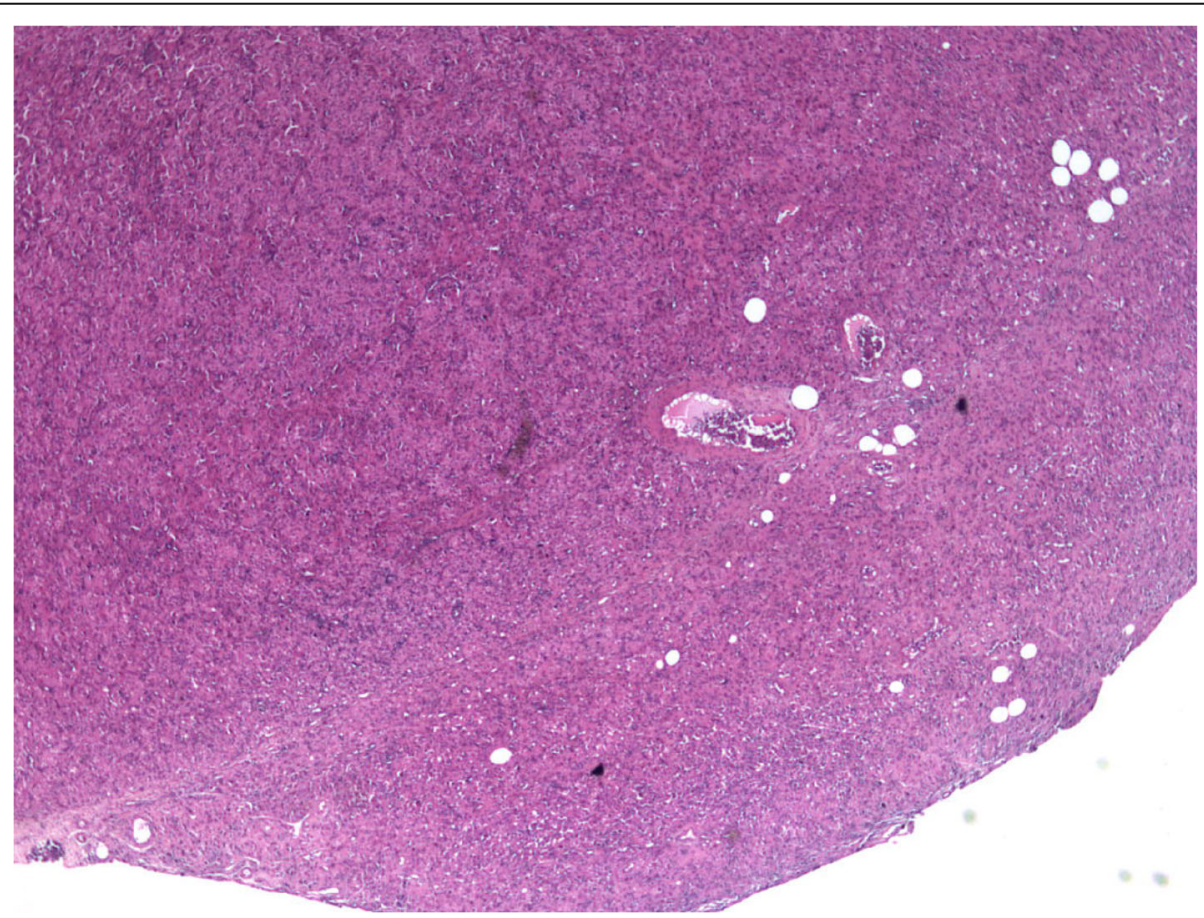

Fig. 2 Photo of the tumor at low magnification (X50). Nodular and well limited tumor composed of sheets of eosinophilic cells with Hematoxylin Eosin and Saffron (HES) stain 


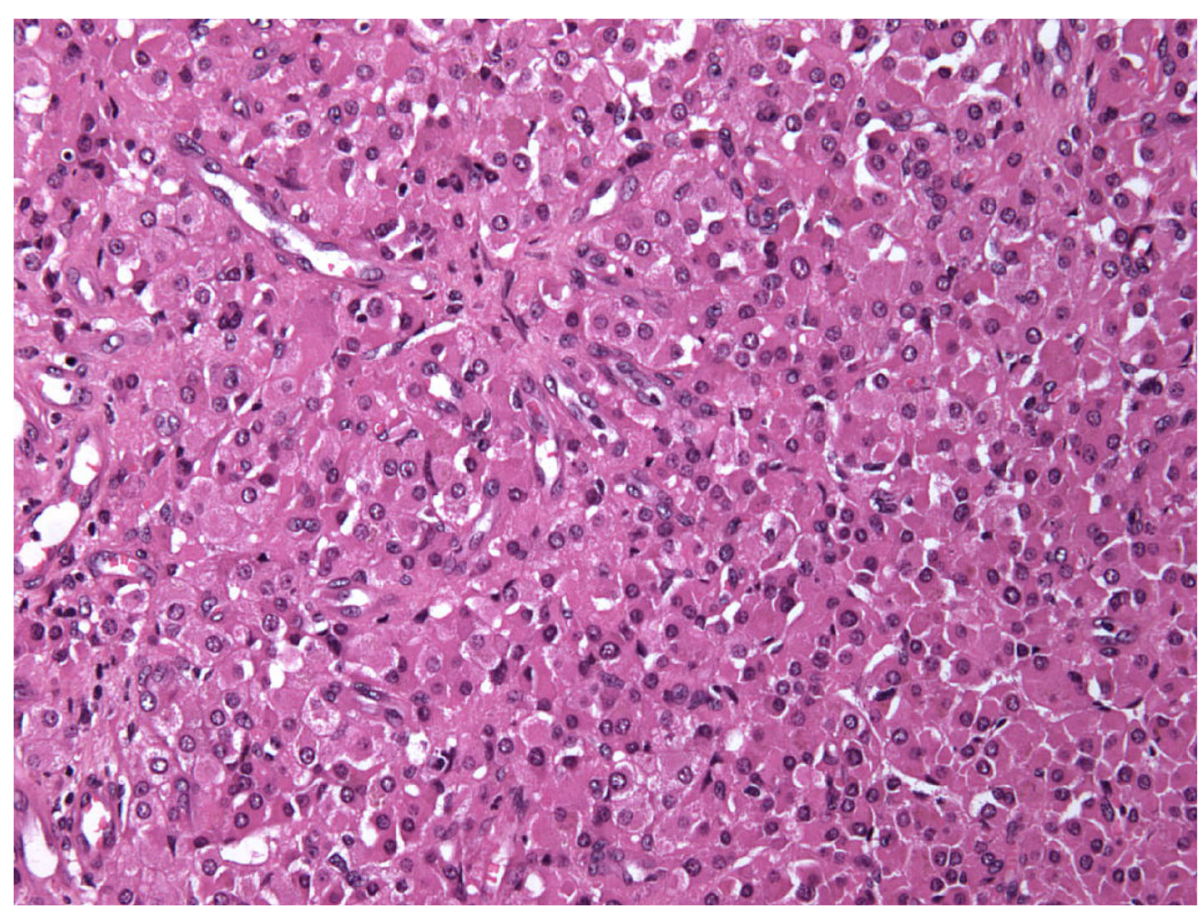

Fig. 3 Photo of the tumor at high magnification (X200). Tumor cells are large with an abundant eosinophilic cytoplasm and round regular nuclei with small nucleoli, according with Leydig cells. Hematoxylin Eosin and Saffron (HES) stain

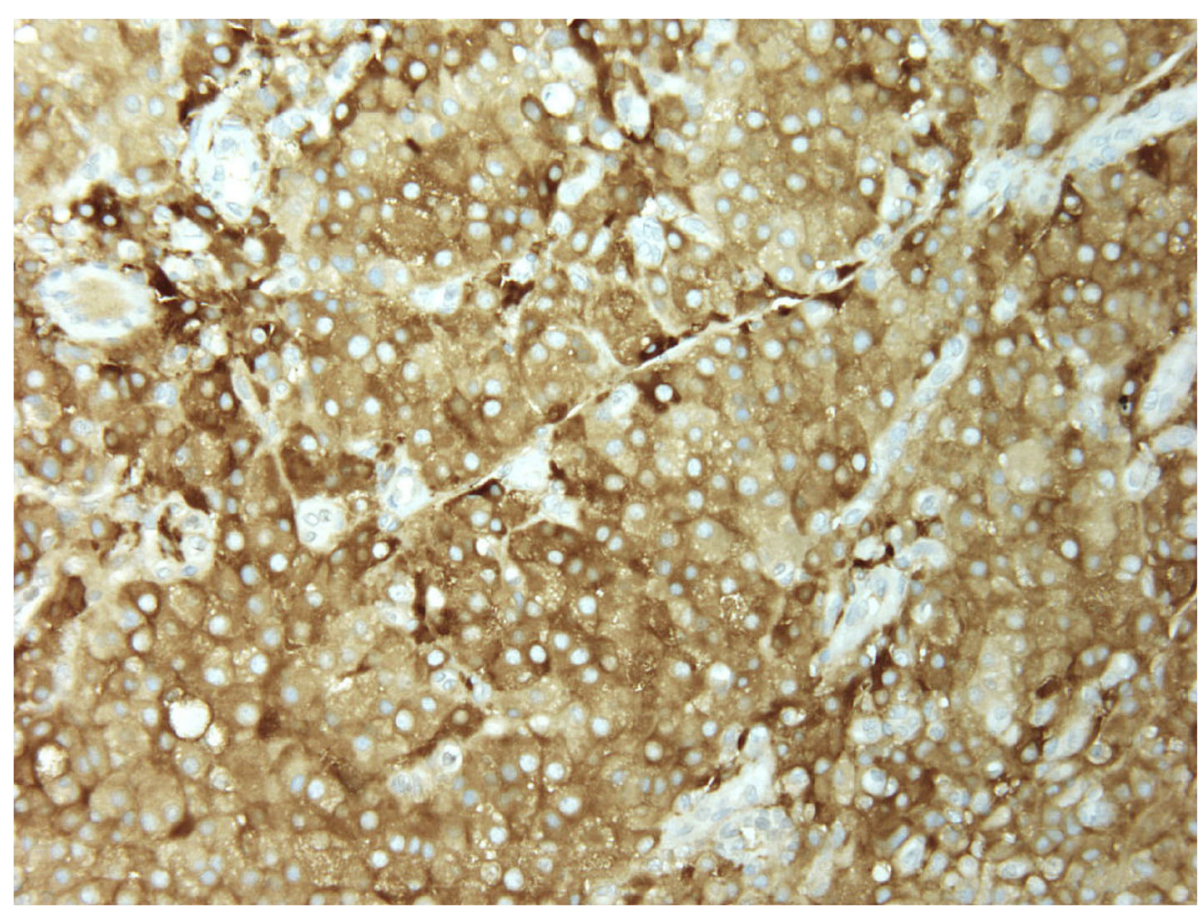

Fig. 4 Photo of the tumor at high magnification (X400). Tumors cells were diffusely stained with antibody to inhibin A(immunoperoxydase). All tumor cells present a diffuse and strong cytoplasmic staining 


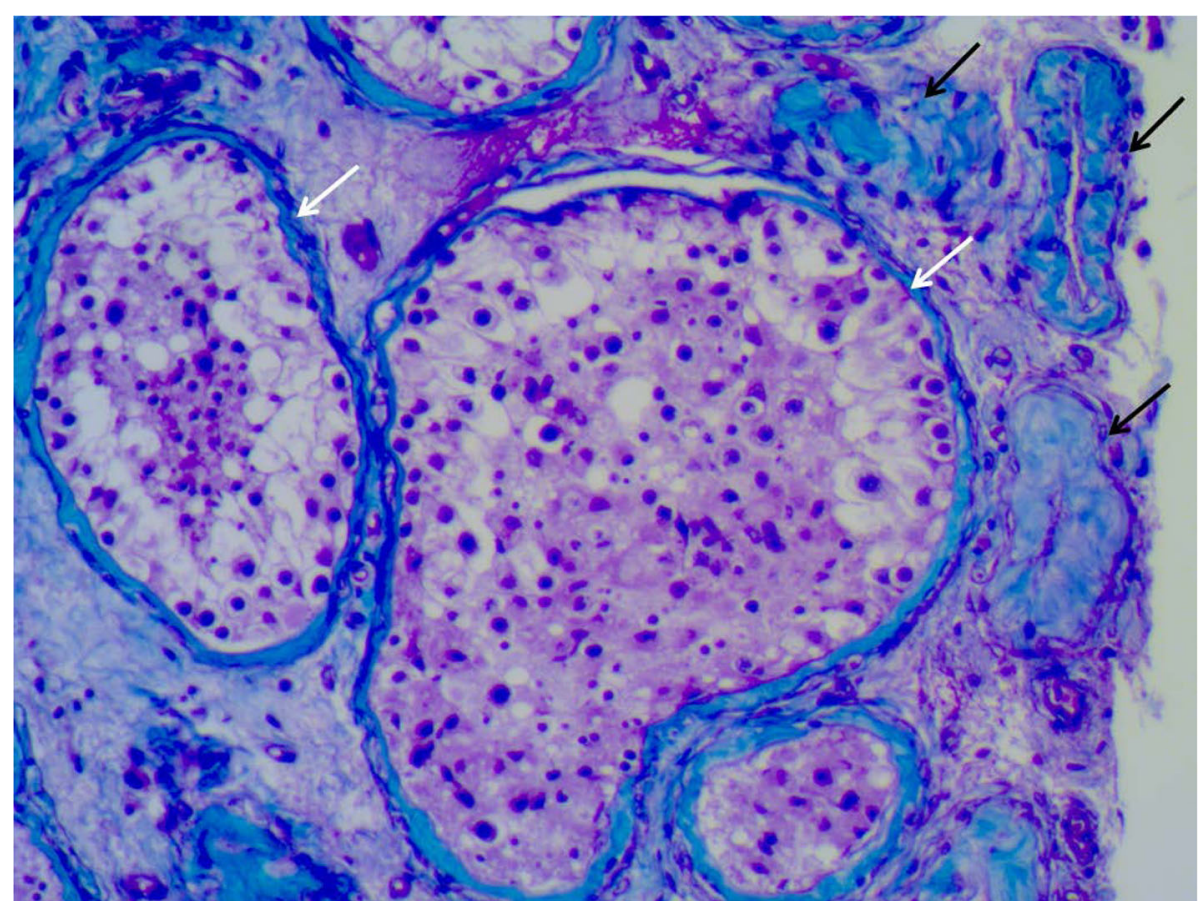

Fig. 5 Photo of the testicular biopsy at high magnification (X100). Histopathological micrograph with hematoxylin-eosin-green FCF stain. The testicular biopsy consists of tubules with hypospermatogenesis (white arrows) mixed with aplasia (black arrows)

In the present case, total suppression of LH levels and almost complete suppression of FSH levels were associated with azoospermia, despite intratesticular testosterone secretion by the tumor, and azoospermia proved to be fully reversible within less than three months after tumor removal and normalization of hormone levels, which shows that normal secretion of gonadotropins, plays a major role in maintaining spermatogenesis. This appears to be in agreement with other (rare) reports of patients with Leydig cell tumors and reversible azoospermia, who did not suffer from other testicular disorders. Interestingly, in these previous reports, the patients were also found to have testosterone secreting Leydig cell tumors with undetectable [15] or markedly reduced [12] gonadotropin levels, which suggests that intratesticular secretion of testosterone by the tumor is not sufficient to prevent azoospermia in spite of marked suppression of LH and FSH secretion. The present paper shows that even with collapsed gonadotropin levels TESE allowed extraction of spermatozoa.

Table 4 Selected hormonal values before and after surgery in 2014

\begin{tabular}{lllll}
\hline & Normal range & 1 month before surgery & 1 day post-operative & 2 months post-operative \\
\hline LH (IU/L) & $0.6-12.0$ & 0.1 & $<0.1$ & 1.6 \\
Total Testosterone $^{\mathrm{a}}(\mathrm{ng} / \mathrm{mL})$ & $2.3-6.7$ & 4.61 & 0.37 & 2.28 \\
SBP $(\mathrm{nmol} / \mathrm{L})$ & $12.5-42.2$ & 34.6 & $\mathrm{ND}$ & 30.7 \\
Delta4 androstenedione $(\mathrm{ng} / \mathrm{mL})$ & $0.4-1.5$ & 10.4 & 1.08 & 0.43 \\
FSH (IU/L) & $1.2-7.8$ & 0.2 & 0.2 & 2.7 \\
Inhibin B $(\mathrm{pg} / \mathrm{mL})$ & $92-316$ & 54 & $\mathrm{ND}$ & 82 \\
\hline
\end{tabular}

IU international unit

$\mathrm{ng} / \mathrm{mL}$ nanogram/ milliliter

nmol/L nanomole/ milliliter

$\mathrm{pg} / \mathrm{mL}$ pictogram/ milliliter

ND not done

${ }^{\mathrm{a}}$ To convert serum testosterone values from $\mathrm{ng} / \mathrm{mL}$ into system international $(\mathrm{SI})$ units (nmol/L), multiply by 3.47 


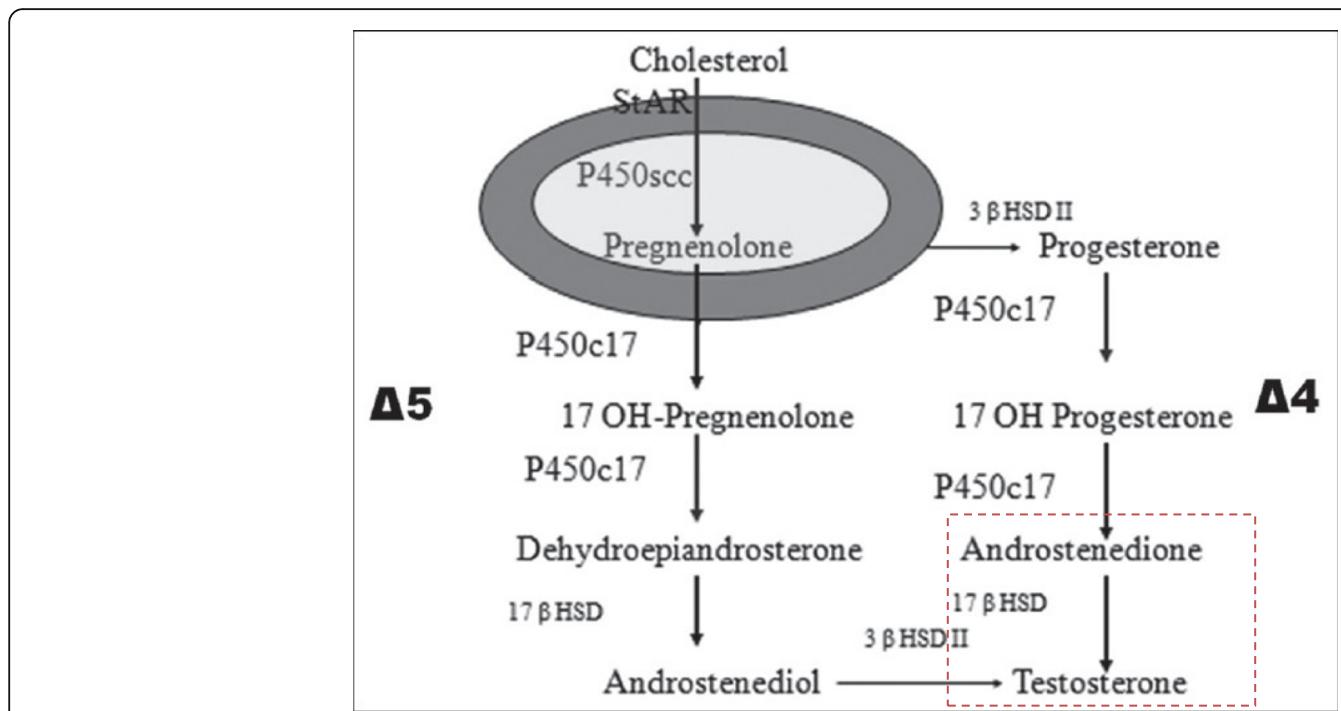

Fig. 6 Testicular Steroidogenesis [21]

\section{Conclusions}

Hormone secreting interstitial cell tumors are rare and have variable clinical presentations. In the case presented in this paper, the diagnosis was made in a context of azoospermia. Few months after tumorectomy, sex steroid levels and spermatogenesis returned to normal and a spontaneous pregnancy occurred.

\section{Abbreviations}

$17 \beta-H S D$ : 17Beta hydroxysteroid dehydrogenase; CT: Computed

tomography; FSH: Follicle stimulating hormone; LH: Luteinizing hormone;

TESE: Testicular sperm extraction

\section{Acknowledgements}

Not applicable.

\section{Funding}

None.

\section{Availability of data and materials}

Not applicable.

\section{Authors' contributions}

JP participated to the patient care, drafted the manuscript. ALB carried out semen analyses. AD participated to draft the manuscript. CL participated to the patient care. PP participated to do magnetic resonance imaging, abdomen and thorax computed tomography and scrotal ultrasonography. FM participated to the patient surgery. XL realized histopathological investigations. VM participated to emend the manuscript, did testicular histology. JMR participated to emend the manuscript. All authors read and approved the final manuscript.

\section{Competing interests}

The authors declare that they have no competing interests.

Ethics approval and consent to participate

Not applicable.

\section{Consent for publication}

Okay.

\section{Author details}

${ }^{1}$ Department of Andrology, Lille University Hospital, Lille, France. ${ }^{2}$ Biology of Reproduction Unit, Lille University Hospital, Lille, France. ${ }^{3}$ Department of Pathology, Lille University Hospital, Lille, France. ${ }^{4}$ Department of Radiology, Lille University Hospital, Lille, France. ${ }^{5}$ EA4308 Gametogenesis and Gamete Quality, University of Lille, Lille, France. ${ }^{6}$ Department of Andrology, CHRU Lille, Hôpital Calmette, Boulevard du Professeur Leclercq, 59037 Lille Cedex, France.

Received: 29 June 2016 Accepted: 14 September 2016

Published online: 08 November 2016

\section{References}

1. Turner WR, Derrick FC, Wohltmann H. Leydig cell tumor in identical twin. Urology. 1976;7(2):194-7.

2. Boulanger P, Somma M, Chevalier S, Bleau G, Roberts KD, Chapdelaine A. Elevated secretion of androstenedione in a patient with a Leydig cell tumour. Acta Endocrinol (Copenh). 1984;107(1):104-9.

3. Kondoh N, Koh E, Nakamura M, Namiki M, Kiyohara H, Okuyama A, et al. Bilateral Leydig cell tumors and male infertility: case report. Urol Int. 1991; 46(1):104-6

4. Gabrilove JL, Nicolis GL, Mitty HA, Sohval AR. Feminizing interstitial cell tumor of the testis: personal observations and a review of the literature. Cancer. 1975;35(4):1184-202.

5. Perez C, Novoa J, Alcañiz J, Salto L, Barcelo B. Leydig cell tumour of the testis with gynaecomastia and elevated oestrogen, progesterone and prolactin levels: case report. Clin Endocrinol (Oxf). 1980;13(5):409-12.

6. Mineur P, De Cooman S, Hustin J, Verhoeven G, De Hertogh R. Feminizing testicular Leydig cell tumor: hormonal profile before and after unilateral orchidectomy. J Clin Endocrinol Metab. 1987:64(4):686-91.

7. Valensi P, Coussieu C, Kemeny JL, Attali JR, Amouroux J, Sebaoun J. Endocrine investigations in two cases of feminizing Leydig cell tumour. Acta Endocrinol (Copenh). 1987;115(3):365-72.

8. Schwarzman MI, Russo P, Bosl GJ, Whitmore WF. Hormone-secreting metastatic interstitial cell tumor of the testis. J Urol. 1989;141(3):620-2.

9. Kerlan V, Nahoul K, Abalain JH, Mangin P, Bercovici JP. Oestrogen secreting Leydig cell tumour and GnRH agonist in-vivo and in-vitro studies. Clin Endocrinol (Oxf). 1992;37(3):221-6.

10. Caron PJ, Bennet AP, Plantavid MM, Louvet JP. Luteinizing hormone secretory pattern before and after removal of Leydig cell tumor of the testis. Eur J Endocrinol Eur Fed Endocr Soc. 1994;131(2):156-9.

11. Daniel L, Lechevallier E, Liprandi A, de Fromont M, Pellissier JF, Coulange C. Malignant Leydig cell tumor of the testis secreting progesterone. Prog En Urol J Assoc Fr Urol Société Fr Urol. 1998;8(6):1047-50. 
12. Mostafid H, Nawrocki J, Fletcher MS, Vaughan NJ, Melcher DH. Leydig cell tumour of the testis: a rare cause of male infertility. Br J Urol. 1998;81(4):651.

13. Fallick ML, Lin WW, Lipshultz LI. Leydig cell tumors presenting as azoospermia. J Urol. 1999;161(5):1571-2

14. Hekimgil M, Altay B, Yakut BD, Soydan S, Ozyurt C, Killi R. Leydig cell tumor of the testis: comparison of histopathological and immunohistochemica features of three azoospermic cases and one malignant case. Pathol Int. 2001;51(10):792-6.

15. Markou A, Vale J, Vadgama B, Walker M, Franks S. Testicular leydig cell tumor presenting as primary infertility. Horm Athens Greece. 2002;1(4):251-4.

16. Carmignani L, Colombo R, Gadda F, Galasso G, Lania A, Palou J, et al. Conservative surgical therapy for leydig cell tumor. J Urol. 2007;178(2):507-11.

17. Sengupta S, Chatterjee U, Sarkar K, Chatterjee S, Kundu A. Leydig cell tumor: a report of two cases with unusual presentation. Indian J Pathol Microbiol. 2010;53(4):796-8.

18. Sönmez N, Ton O, Arısan S, Klınç F, Eken K, Güney S. Bilateral Leydig cell tumor of the testis: a case report. Contemp Oncol Pozn Pol. 2012;16(4):356-9.

19. Straume AH, Løvås K, Miletic H, Gravdal K, Lønning PE, Knappskog S. Elevated levels of the steroidogenic factor 1 are associated with overexpression of CYP19 in an oestrogen-producing testicular Leydig cell tumour. Eur J Endocrinol Eur Fed Endocr Soc. 2012;166(5):941-9.

20. Magdasy S, Bogenmann L, Batisse-Lignier M, Roche B, Franck F, Desbiez F, et al. Leydig cell tumor in a patient with 49, XXXXY karyotype: a review of literature. Reprod Biol Endocrinol RBE. 2015;13:72.

21. Kumar A, Shekhar S, Dhole B. Thyroid and male reproduction. Indian J Endocrinol Metab. 2014;18(1):23-31.

\section{Submit your next manuscript to BioMed Central} and we will help you at every step:

- We accept pre-submission inquiries

- Our selector tool helps you to find the most relevant journal

- We provide round the clock customer support

- Convenient online submission

- Thorough peer review

- Inclusion in PubMed and all major indexing services

- Maximum visibility for your research

Submit your manuscript at www.biomedcentral.com/submit 